\title{
Przydatność stali mikrostopowej 28HGVB do konstrukcji spawanych
}

\author{
The usefulness of microalloyed steel 28HGVB \\ for welded structures
}

\section{Streszczenie}

W artykule omówiono problem występujący pomiędzy hartownością i spawalnością stali stosowanych na elementy maszyn roboczych. W badaniach laboratoryjnych stal 28HGVB z mikrododatkiem boru poddano obróbce cieplnej oraz próbom spawania. Próbne złącza spawane metodą 111 testowano metodami nieniszczącymi i niszczącymi. Stwierdzono, że stal z dodatkiem 0,003 \% boru posiada zdolność utwardzania metodą konwencjonalnej obróbki cieplnej do 330 - 470 HV na głębokość do 30 mm. Testy złączy spawanych wykazały pełną przydatność badanej stali do zastosowania na konstrukcje spawane.

Słowa kluczowe: stal mikrostopowa, spawalność, hartowność, regeneracja lemiesza

\section{Abstract}

The article discusses the problem between hardenability and weldability of steel used for elements of working machines. In laboratory examination of the microalloyed steel 28HGVB with boron was heat treated and tests of welding were performed. Test pieces executed using 111 welding process were tested by destructive and non-destructive methods. It was found that the steel containing $0.003 \%$ boron has the ability to harden by conventional heat treatment to $330-470 \mathrm{HV}$ at a depth of $30 \mathrm{~mm}$. Examinations of welded joints showed full usability of the tested steel for weld constructions.

Keywords: micro-alloy steel, weldability, hardenability, regeneration of ploughshare

\section{Wstęp}

Szereg elementów maszyn roboczych i urządzeń transportowych wykonywanych jest z materiałów odpornych na ścieranie. Problemy z technologią takich materiałów polegają na tym, że materiały odporne na zużycie są trudne do łączenia metodą spawania. Budowa monolitycznych konstrukcji w których korpusy i elementy nośne wytwarzane są ze zwykłych stali węglowych, a elementy robocze ze stali utwardzanych metoda obróbki cieplnej jest niekiedy niemożliwe. Przy zawartości węgla powyżej $0,3 \%$ stale można obrabiać cieplnie ale są trudno spawalne. Stale spawalne z kolei nie dają się utwardzać przez hartowanie i odpuszczanie. Rozwiązaniem problemu jest zastosowanie konstrukcji bimetalowych to jest takich, w których element roboczy wykonany ze stali utwardzonej jest przyspawany do części nośnej. Zaletą takiego rozwiązania jest możliwość regeneracji przez odcięcie zużytego fragmentu roboczego i przyspawania nowego. Próby takie autor prowadził dla lemieszy pługów rolniczych [17]. Rozwiązania bimetalowe mogą być stosowane dla takich konstrukcji zużywalnych części maszyn i urządzeń jak:

- okładziny form do produkcji materiałów budowlanych,

- ostrza i płyty krawędziowe kruszarek i ładowarek,

- ogniwa przenośników zgrzebłowych,

- elementy robocze maszyn rolniczych, budowlanych i wydobywczych,
- przenośniki ślimakowe,

- łopaty młynów wentylatorowych do kotłów.

$Z$ analizy literatury i własnych badań autora $[3,11,12]$ wynika, że materiałem posiadającym obydwie cechy jednocześnie t.j. hartowność i spawalność jest stal mikrostopowa z borem.

W budowie maszyn roboczych wykorzystywane jest szereg stali $\mathrm{z}$ borem: 15G2ATB, 15G2ANbTB, 13HNMB, 14HNMBCu, 21HG2SB [1], 15B36H, 25G2B [16], HARDOX i VELDOX [8].

Stale z mikro dodatkiem boru stosowane były już podczas II wojny światowej. Określane były jako stale bainityczne o wysokiej wytrzymałości i odporności na ścieranie. Uzyskanie struktury bainitycznej było możliwe na drodze normalizowania cienkich przekrojów przy szybkim chłodzeniu. Utwardzenie elementów o grubości kilkudziesięciu mm możliwe jest przy zastosowaniu hartowania i odpuszczania. Najkorzystniejsze działanie boru odnotowano w zakresie 0,003 - 0,004 \%. Wpływ boru na hartowność stali oraz na położenie linii na wykresie CTPc-S opisane zostały szczegółowo w pracy J. Brózdy, J. Pilarczyka i M. Zemana [1]. Dodatek boru oraz innych pierwiastków ma odzwierciedlenie W wartości równoważnika węglowego $C_{E}$. Wprowadzenie boru miało na celu uzyskanie dużej głębokości hartowania w stalach spawalnych o niskiej zawartości węgla. W proce-

Dr hab. inż. Jan Stabryła - Uniwersytet Warmińsko-Mazurski w Olsztynie.

Autor korespondencyjny/Corresponding author. janes@uwm.edu.pl 
sie wytopu stali z borem wymagane jest bardzo dobre odtlenienie kąpieli przez dodatek aluminium. W przypadku niedostatecznego odtlenienia stali, jednocześnie $\mathrm{z} \mathrm{Al}_{2} \mathrm{O}_{3}$ tworzy się tlenek $\mathrm{B}_{2} \mathrm{O}_{3}$, a w stanie stałym stabilne azotki AIN i BN co obniża stężenie boru wpływające korzystnie na hartowność stali poniżej 0,0008\%. Przydatność stali niskostopowych o podwyższonej wytrzymałości do spawania można oceniać na podstawie szeregu wskaźników. W opracowaniu "Spawalnicze wykresy przemian austenitu CTPc-S" autorzy [1] przedstawili wyniki badania cykli cieplnych spawania i ich wpływu na przemiany strukturalne oraz właściwości SWC. Przykład wykresu CTPc-S dla stali 21HG2SB o składzie zestawionym w tablicy I, zbliżonym do składu stali stanowiącej przedmiot badań, przedstawiono na rysunku 1.

Z zamieszczonego wykresu wynika, że przy czasie stygnięcia złącza w zakresie temperatury $800-500{ }^{\circ} \mathrm{C}$ wynoszącym ponad 20 sekund powstanie korzystna struktura bainityczna o twardości ok. $400 \mathrm{HV}$ i udarności na poziomie $\mathrm{KCV}=30 \mathrm{~J} / \mathrm{cm}^{2}$. Strefa zmian strukturalnych $\mathrm{w}$ obszarze przegrzania materiału rodzimego ciepłem krystalizacji spoiny SWC (HAZ) jest jednym z najistotniejszych miejsc decydujących o wytrzymałości złącza. Większość awarii konstrukcji złączy o poprawnej budowie makro jest spowodowana pękaniem strefy wpływu ciepła. Zjawiska cieplne w stali podatnej na utwardzanie mogą spowodować wzrost twardości i koncentrację naprężeń w tym obszarze. Ponadnormatywny wzrost twardości SWC powyżej $100 \mathrm{HV}$ w porównaniu do spoiny lub materiału rodzimego może spowodować skłonność złącza do zimnych pęknięć [14].
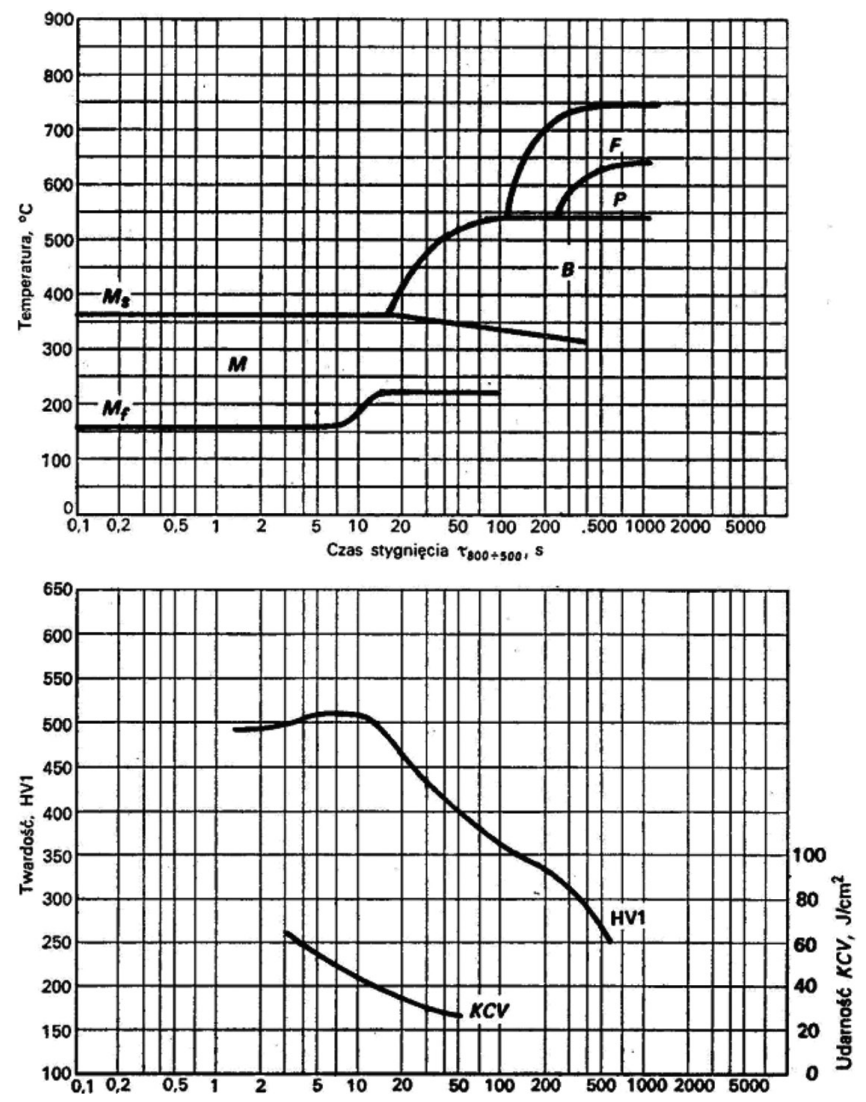

Rys. 1. Wykres CTPc-S dla stali 21HG2SB [1]

Fig. 1. CCT welding diagrams for $21 \mathrm{HG} 2 \mathrm{SB}$ steel [1]
Zimne pęknięcia wywołane są równoczesnym oddziaływaniem trzech czynników: małej plastyczności SWC o strukturze martenzytycznej lub martenzytyczno-bainitycznej, wodoru dyfundującego z metalu spoiny do SWC oraz naprężeń wywołanych skurczem złącza spawanego. Wykresy CTPc-S informują jedynie o skłonności stali do tworzenia twardej struktury. Twardość SWC można zmniejszyć przez zastosowanie wstępnego podgrzania złącza spawanego lub zwiększenie energii liniowej łuku. Jednocześnie ze wzrostem energii zwiększają się naprężenia w złączach spawanych i takie rozwiązanie możliwe jest tylko przy skurczu swobodnym. Degradacja struktury może być wywołana wodorem dyfundującym do stali podczas wytopu, procesów spawania, a także podczas eksploatacji w środowisku wodoronośnym. Obszerne badania autora [12,13], dowiodły, że stale z borem posiadają podwyższoną odporność na degradację wodorową. Bor rozmieszczając się na granicach ziaren i w defektach struktury, utrudnia dyfuzję wodoru do stali zarówno podczas spawania jak i podczas eksploatacji. Z tego to powodu stal z borem jest zalecana jako materiał konstrukcyjny odporny na złożone zużycie wodorowo - ścierne.

Odporność na kruche pękanie złącza spawanego zależna jest od plastyczności poszczególnych jego elementów składowych, tzn. materiału rodzimego, spoiny i strefy wpływu ciepła. Pomimo właściwego doboru gatunku stali i stopiwa, zapewniających wymaganą odporność na kruche pękanie materiału rodzimego i spoiny, SWC o małej plastyczności może być miejscem inicjowania i rozprzestrzeniania się pęknięć kruchych. Właściwości SWC, a szczególnie jej odporność na kruche pękanie można w pewnym zakresie (niekiedy dość szerokim) regulować, zmieniając czas stygnięcia złącza spawanego, na który z kolei można wpływać przez zmianę energii liniowej łuku i temperaturę początkową spawanych elementów. Zamieszczone na większości wykresów krzywe udarności symulowanej strefy wpływu ciepła pozwalają na ocenę wpływu czasu stygnięcia $T_{800 \div 500}$ na odporność na kruche pękanie SWC w złączu spawanym. Stosując stal z borem na krawędzie narzędzi roboczych unika się trzeciego czynnika jakim są naprężenia spawalnicze normalne do osi spoiny.

Wstępną ocenę spawalności metalurgicznej można dokonać na podstawie obliczenia równoważnika węglowego przedstawionego dla stali z borem w postaci zależności (1).

\section{$\mathrm{C}_{\mathrm{E}}=\mathrm{C}+\mathrm{Si} / 30+(\mathrm{Mn}+\mathrm{Cr}+\mathrm{Cu}) / 20+\mathrm{Ni} / 60+\mathrm{Mo} / 15+\mathrm{V} / 10+5 \mathrm{~B} \%$}

Przy obliczonych wartościach równoważnika kryterium spawalności wynosi:

$\mathrm{C}_{\mathrm{E}}<0,15$ - stal odporna na pęknięcia,

$0,15<C_{E}<0,45$ - stal częściowo odporna na pęknięcia

$\mathrm{C}_{\mathrm{E}}>0,45$ - stal skłonna do pęknięć.

Ze względu na spodziewane dla stali z borem wartości równoważnika $\mathrm{C}_{\mathrm{E}} \mathrm{w}$ środkowym zakresie, nieodzowne jest sprawdzenie zachowania się badanej stali metoda wykonania złącza próbnego, które będzie poddane testom praktycznym stosowanym w procedurze uznawania technologii spawania wg PN-EN 15614-1 [9].

Spawalność technologiczna i konstrukcyjna praktycznie oceniana może być w próbach laboratoryjnych przez badanie nieniszczące VT, (RT lub UT), badania strukturalne makro i mikroskopowe oraz próbę gięcia i rozciągania [3].

Tablica I. Skład chemiczny stali 21 HG2SB [1]

Table I. The chemical composition of the 21 HG2SB steel [1]

Zawartość pierwiastków, \%

\begin{tabular}{|c|c|c|c|c|c|c|c|c|c|}
\hline C & Mn & Si & P & S & Al & Cr & Ni & Cu & B \\
\hline 0,22 & 1,41 & 0,85 & 0,023 & 0,01 & 0,05 & 0,53 & 0,10 & 0,15 & 0,003 \\
\hline
\end{tabular}


Mikrododatku boru wg wielu autorów [2,6,7,10], wpływa na właściwości technologiczne stali przez następujące mechanizmy:

- tworzy twarde fazy międzywęzłowe $\mathrm{Fe}_{2} \mathrm{~B}$ i FeB, borki $\mathrm{CrB}$, $\mathrm{VB}_{2}, \mathrm{Ni}_{2} \mathrm{~B}, \mathrm{TiB}$, węgliki $\mathrm{B}_{4} \mathrm{C}, \mathrm{B}_{6} \mathrm{C}$ i $\mathrm{Fe}_{23}(\mathrm{C}, \mathrm{B})_{6}$,

- zwiększa dyspersję faz strukturalnych podczas hartowania,

- polepsza hartowność stali średniowęglowych,

- zwiększa wytrzymałość granic ziaren martenzytu,

- rozmieszcza się na granicach ziaren i w defektach strukturalnych - utrudnia dyfuzję wodoru.

\section{Cel, przedmiot i zakres badań}

W dostępnych publikacjach brak jest danych dotyczących spawalności stali 28 HGVB krajowej produkcji. Celem badań było określenie możliwości zastosowania ulepszanej cieplnie stali mikrostopowej 28HGVB z borem do wytwarzania i regeneracji elementów maszyn roboczych łączonych do konstrukcji podstawowych za pomocą spawania. Skład chemiczny badanej stali zamieszczono w tablicy II.

Zakres badań obejmował określenie zarówno możliwości utwardzenia badanej stali za pomocą obróbki cieplnej jak też i cech technologicznych złącza spawanego. W ramach oceny przeprowadzono dwie grupy eksperymentów. We wstępnych badaniach oceniono hartowność stali 28HGVB metodą Jominy'ego oraz możliwość uzyskania utwardzenia na drodze hartowania $z$ austenityzacją w temperaturze $880^{\circ} \mathrm{C}$ i odpuszczania w temperaturze $220^{\circ} \mathrm{C}, 350^{\circ} \mathrm{C}$ i $500^{\circ} \mathrm{C}$. Celem zastosowania różnych temperatur odpuszczania była ocena możliwości uzyskania zróżnicowanego utwardzenia stali z przeznaczeniem do konkretnych warunków pracy oraz określenie odporności na obciążenia dynamiczne. W drugiej części eksperymentu określono spawalność testowanej stali:

a) na podstawie wyliczenia równoważnika węglowego wg zależności (1) - CE = 0,3411,

b) na podstawie badań laboratoryjnych złączy próbnych wykonanych w oparciu o opracowaną instrukcję spawania.

Złącza spawane poddano próbom przewidzianym normą PN-EN 15614-1:

- badania wizualne VT (PN-EN 970),

- badania radiograficzne RT (PN-EN 1435),

- pomiary twardości w złączu spawanym HV (PN-EN 1043-1),

- badania makroskopowe złącza MA (PN-EN 1321),

- badania mikroskopowe złącza MI (PN-EN 1321),

- próba rozciągania RM (PN-EN 895)

- próba zginania MG (PN-EN 910)

\section{Metodyka badań i wyniki}

Podatność stali na utwardzanie metodą obróbki cieplnej oceniano przez pomiar twardości powierzchniowej obrobionych próbek na twardościomierzu HPO 250 me-

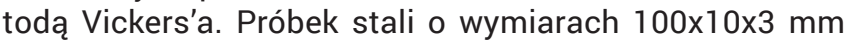
austenityzowano $\mathrm{w}$ temperaturze $880{ }^{\circ} \mathrm{C}$, chłodzono $\mathrm{w}$ wodzie, a następnie odpuszczanie w temperaturze $500{ }^{\circ} \mathrm{C}$, $350{ }^{\circ} \mathrm{C}$ i $220{ }^{\circ} \mathrm{C}$. Do obróbki stosowano piec komorowy

Tablica II. Skład chemiczny stali 28HGVB

Table II. The chemical composition of the 28HGVB steel

\begin{tabular}{|c|c|c|c|c|c|c|c|c|c|c|}
\hline \multicolumn{10}{|c|}{ Zawartość pierwiastków, \% } & Al \\
\hline C & Mn & Si & P & S & Cr & Ni & Cu & V & B \\
\hline 0,25 & 1,12 & 0,32 & 0,027 & 0,03 & 0,05 & 0,46 & 0,07 & 0,11 & 0,08 & 0,003 \\
\hline
\end{tabular}

Tablica III. Wyniki pomiarów twardości próbek obrabianych cieplnie

Table III. The results of the hardness measurement of heat-treated samples

\begin{tabular}{|c|c|c|c|c|c|}
\hline Obróbka cieplna & Nr próbki & HV 30 & HV śr & Kąt zgięcia & Średni kąt zgięcia \\
\hline \multirow{3}{*}{$\begin{array}{c}\text { Hartowanie } 880^{\circ} \mathrm{C} \\
\text { odpuszczanie } \\
500^{\circ} \mathrm{C}\end{array}$} & 1 & 332 & \multirow{3}{*}{331} & $76^{\circ}$ & \multirow{3}{*}{$78^{\circ} 30^{\prime}$} \\
\hline & 2 & 333 & & $79^{\circ}$ & \\
\hline & 3 & 329 & & $80^{\circ} 30^{\prime}$ & \\
\hline \multirow{3}{*}{$\begin{array}{c}\text { Hartowanie } 8800^{\circ} \mathrm{C} \\
\text { odpuszczanie } \\
350^{\circ} \mathrm{C}\end{array}$} & 4 & 443 & \multirow{3}{*}{426} & $61^{\circ} 30^{\prime}$ & \multirow{3}{*}{$61^{\circ} 37^{\prime}$} \\
\hline & 5 & 393 & & $63^{\circ}$ & \\
\hline & 6 & 441 & & $60^{\circ} 30^{\prime}$ & \\
\hline \multirow{3}{*}{$\begin{array}{c}\text { Hartowanie } 8800^{\circ} \mathrm{C} \\
\text { i odpuszczanie } \\
220^{\circ} \mathrm{C}\end{array}$} & 7 & 470 & \multirow{3}{*}{467} & $58^{\circ}$ & \multirow{3}{*}{$55^{\circ}$} \\
\hline & 8 & 480 & & $53^{\circ}$ & \\
\hline & 9 & 449 & & $54^{\circ}$ & \\
\hline
\end{tabular}

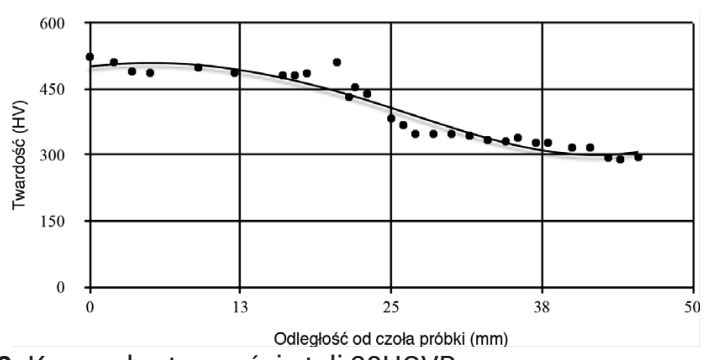

Rys. 2. Krzywa hartowności stali 28HGVB

Fig. 2. Hardenability curve for $28 \mathrm{HGVB}$ steel

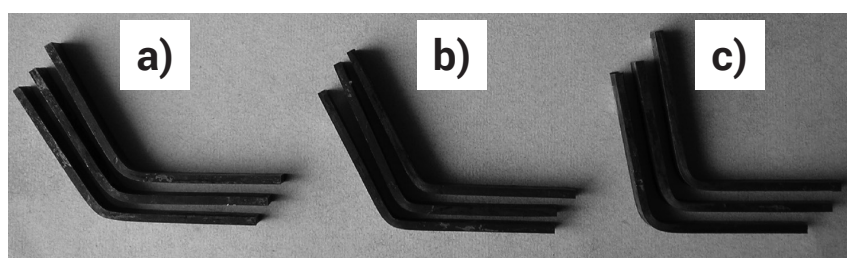

Rys. 3. Próbki gięte udarowo a) $\mathrm{t}_{\text {odp }} 220^{\circ} \mathrm{C}$ - kąt $55^{\circ}$, b) $\mathrm{t}_{\text {odp }} 350^{\circ} \mathrm{C}$ - kąt $61^{\circ} 30^{\prime}$, c) todp $350^{\circ} \mathrm{C}$ - kąt $78^{\circ} 30^{\prime}$

Fig. 3. The impact bend samples a) t temp $220^{\circ} \mathrm{C}$ - angle of $55^{\circ}$, b) $t_{\text {temp }} 350^{\circ} \mathrm{C}$ - angle of $61^{\circ} 30$,; c) t temp $350^{\circ} \mathrm{C}$ - angle of $78^{\circ} 30^{\prime}$ 
Nabertherm LH 15/14. Próbki po ocenie twardości obciążano dynamicznie na młocie Harpy'ego PSW 30. O wpływie temperatury odpuszczania na plastyczności próbek świadczy kąt zgięcia - rysunek 3. Żadna z próbek nie uległa pęknięciu. W tablicy III zestawiono wyniki pomiarów twardości HV30 i odporności na uderzenia próbek stali hartowanych i odpuszczanych. Żadna próbka nie uległa pęknięciu.

Hartowność stali oceniano na próbkach $\varphi 25 \times 100$ mm metodą chłodzenia od czoła (próba JOMINY'EGO). Na podstawie pomiarów twardości na próbce walcowej wyznaczono krzywą hartowności - rysunek 2.

Tablica IV. Karta Instrukcji Technologii spawania złącza próbnego Table IV. Welding Procedure Specyfication test joints
Celem przeprowadzenia oceny praktycznej spawalności stali 28HGVB opracowano próbną instrukcję spawania nr pWPS-1/14/UWM. (tabl. IV).

Wg opracowanej instrukcji wykonano złącza próbne, które poddano badaniom.

\section{Badania wizualne złączy wg PN-EN 970}

Złącza próbne po oczyszczeniu poddano analizie wizualnej na obecność zewnętrznych niezgodności spawalniczych. Wyniki oględzin i oceny zamieszczono w tablicy V.

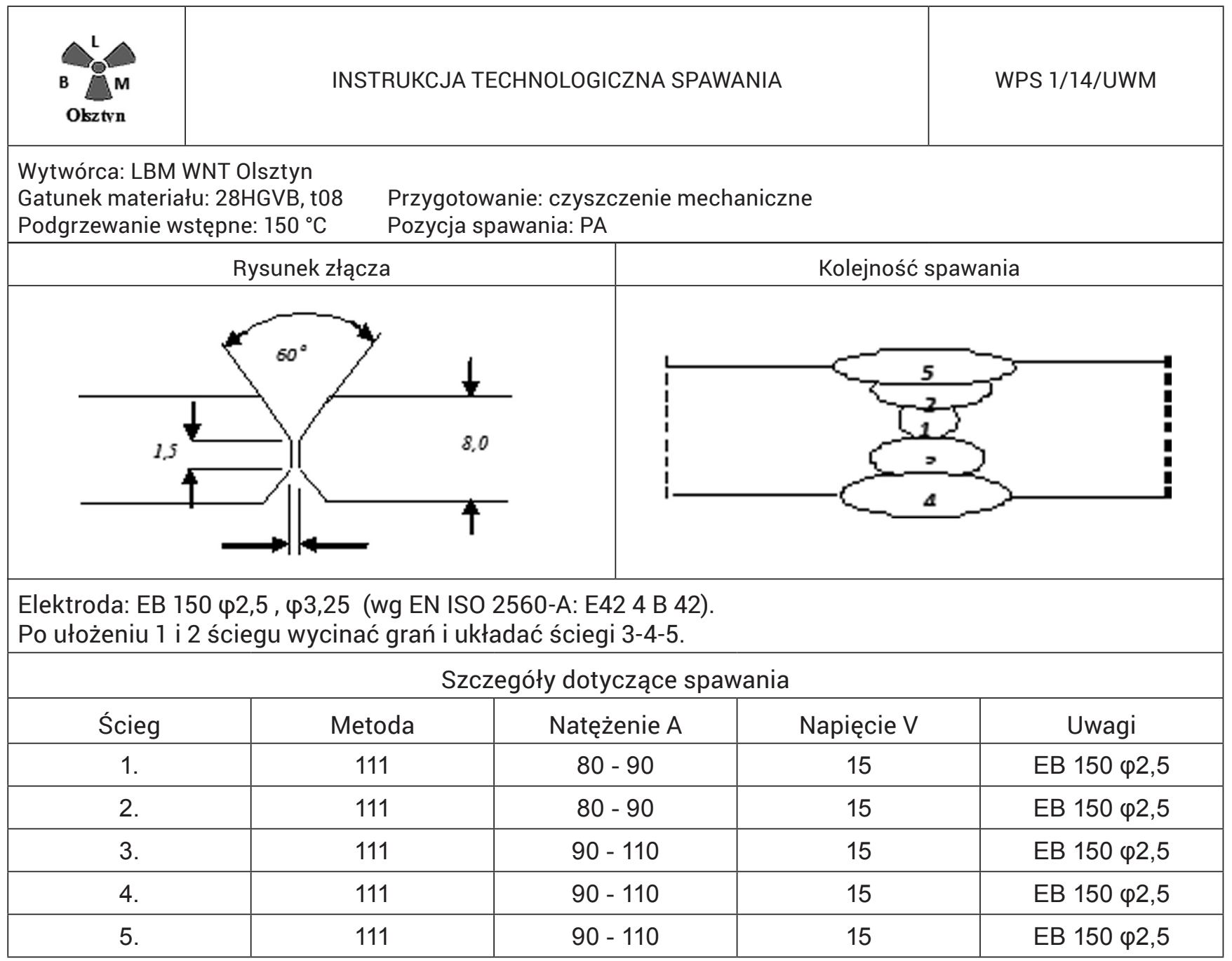

Tablica V. Warunki i wyniki badań wizualnych złączy próbnych Table V. Conditions and results of visual testing of test joints

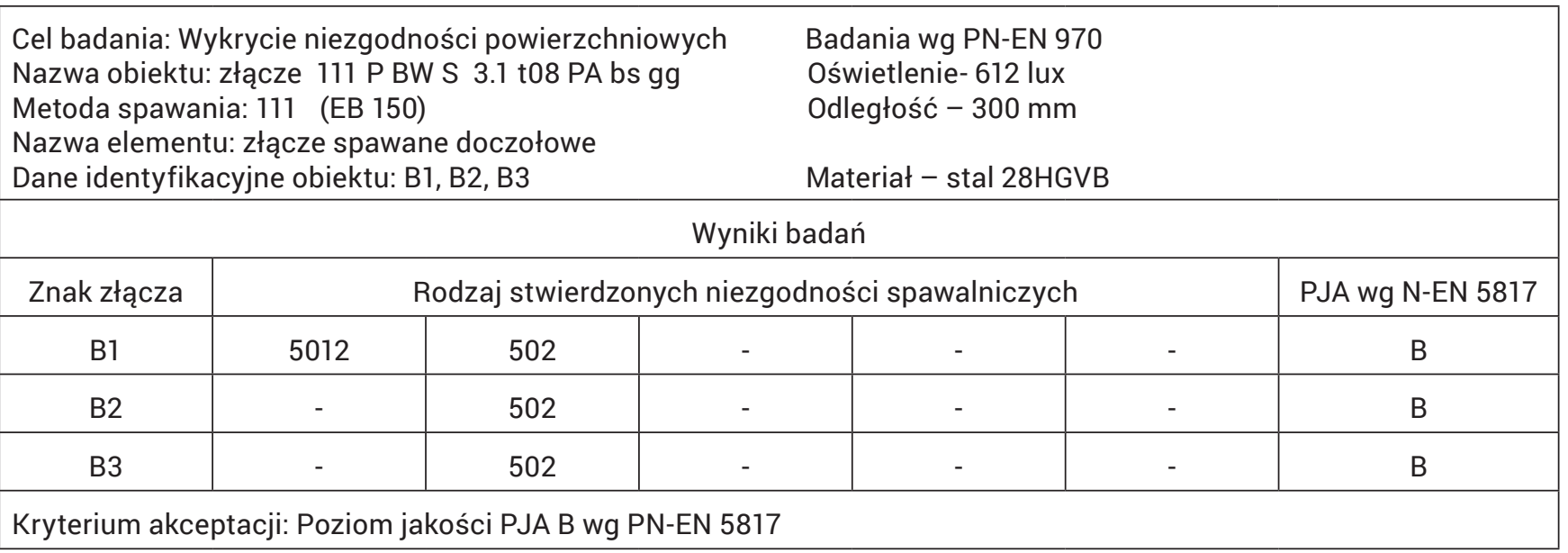




\section{Badania radiograficzne RT wg PN-EN 1435}

Po pozytywnym zakwalifikowaniu złączy na podstawie badań wizualnych powierzchniowych, przekazano je do badań radiograficznych celem wykrycia niezgodności wewnętrznych. Warunki i wyniki badań zestawiono w tablicy $\mathrm{VI}$, a na rysunek 4 - obraz radiogramu.

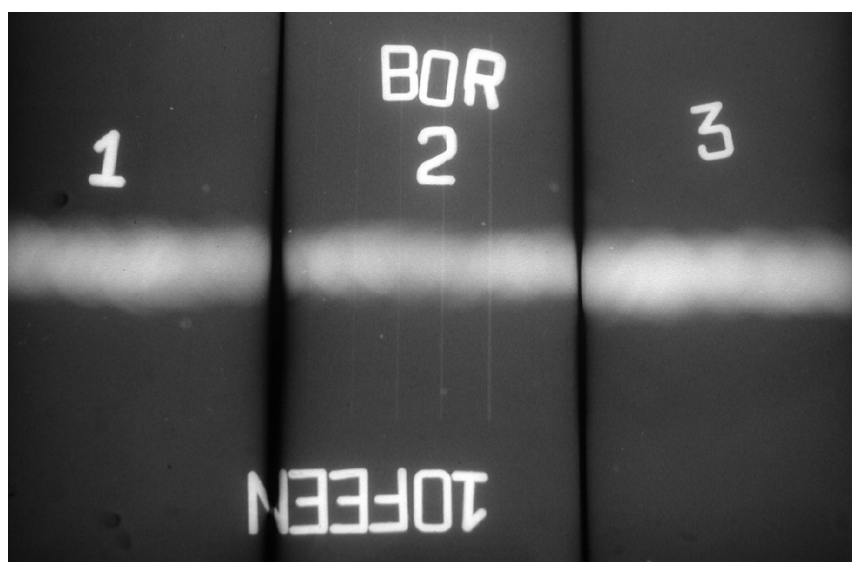

Rys. 4. Radiogram złączy próbnych

Fig. 4. Radiograph of test joint

\section{Pomiary twardości w złączu spawanym HV wg PN-EN 1043-1}

Twardość, a w szczególności różnica rozkładu twardości w przekroju złącza dostarcza informacji o jego poprawnej lub błędnej budowie. Wysoka twardość SWC wskazuje na takie zmiany struktury, które mogą wywołać obniżenie podatności na odkształcenia plastyczne, a w efekcie jej pękanie. Wykonano po dwa pomiary twardości w każdej strefie złącza. Przy złączu dwustronnie spawanym, rząd odcisków znajdował się po obydwu stronach - rysunek 5 .

Pomiarów twardości dokonano na przekroju poprzecznym przy użyciu twardościomierza HPO 250 metodą Vickers'a HV10. Wyniki zestawiono w tablicy VII.

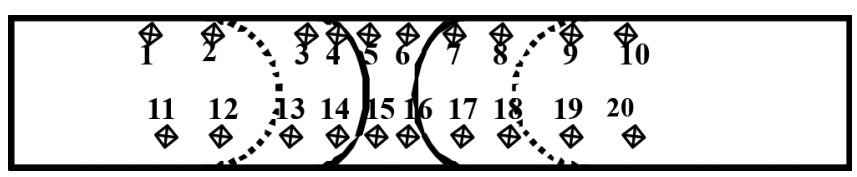

Rys. 5. Miejsca pomiarów twardości HV10 na przekroju złącza

Fig. 5. Places HV10 hardness measurements on cross section of joint
Tablica VII. Rozkład twardości w złączach próbnych wg rysunku 5 Table VII. Distribution of hardness of test joints shown in the figure 5

\begin{tabular}{|c|c|c|c|c|c|}
\hline \multicolumn{6}{|c|}{$\begin{array}{l}\text { Twardościomierz : HPO } 250 \text { nr fab. } 308 / 336 \\
\text { Siła obciążenia: HV 10, Czas obciążenia 15s. } \\
\text { Kryterium twardości: dla stali 28HGVB: max } 420 \text { HV }\end{array}$} \\
\hline $\begin{array}{l}\text { Miejsce } \\
\text { pomiaru }\end{array}$ & Obszar & \multicolumn{4}{|c|}{ Wyniki HV 10} \\
\hline \multirow{8}{*}{$\begin{array}{l}\text { Materiał } \\
\text { rodzimy }\end{array}$} & 1 & 238 & 206 & 224 & \multirow{8}{*}{232} \\
\hline & 2 & 236 & 233 & 232 & \\
\hline & 9 & 254 & 243 & 232 & \\
\hline & 10 & 238 & 249 & 212 & \\
\hline & 11 & 243 & 240 & 221 & \\
\hline & 12 & 230 & 206 & 221 & \\
\hline & 19 & 232 & 243 & 235 & \\
\hline & 20 & 228 & 236 & 232 & \\
\hline \multirow{8}{*}{ SWC } & 3 & 322 & 383 & 348 & \multirow{8}{*}{341} \\
\hline & 4 & 348 & 376 & 345 & \\
\hline & 7 & 348 & 345 & 327 & \\
\hline & 8 & 342 & 345 & 339 & \\
\hline & 13 & 351 & 342 & 339 & \\
\hline & 14 & 336 & 336 & 351 & \\
\hline & 17 & 330 & 336 & 312 & \\
\hline & 18 & 317 & 319 & 348 & \\
\hline \multirow{4}{*}{ Spoina } & 5 & 236 & 194 & 221 & \multirow{4}{*}{222} \\
\hline & 6 & 232 & 207 & 219 & \\
\hline & 15 & 253 & 206 & 225 & \\
\hline & 16 & 236 & 207 & 230 & \\
\hline
\end{tabular}

\section{Badania makroskopowe MA i mikroskopowe MI złączy wg PN-EN 1321}

Budowę makroskopową złączy trawionych odczynnikiem Adlera ukazano na przekrojach poprzecznych - rysunek 6 .

Tablica VI. Wyniki oceny radiogramów próbnych złączy spawanych Table VI. The evaluation results of welds radiographic testing

\begin{tabular}{|c|c|c|c|c|c|c|c|c|}
\hline \multicolumn{4}{|c|}{$\begin{array}{l}\text { Laboratorium Badań Materiałowych } \\
\text { Aparat TRAKIS HETRA MXR } 200\end{array}$} & \multicolumn{4}{|c|}{ PROTOKÓ $Ł$ z badań radiograficznych } & RT -1 \\
\hline \multirow{3}{*}{ Lp } & \multirow{3}{*}{$\begin{array}{l}\text { Grupa radio- } \\
\text { graficzna } \\
\text { (chyba, że się } \\
\text { nie zmieści }\end{array}$} & \multirow{3}{*}{$\begin{array}{l}\text { Oznaczenie } \\
\text { radiogramu }\end{array}$} & \multirow{3}{*}{$\begin{array}{c}\text { Klasa } \\
\text { badania }\end{array}$} & \multicolumn{3}{|c|}{ Klasa radiogramu } & \multirow{3}{*}{$\begin{array}{l}\text { Wykryte } \\
\text { niezgodności }\end{array}$} & \multirow{3}{*}{$\begin{array}{l}\text { PJA wg PN } \\
\text {-EN } 5817\end{array}$} \\
\hline & & & & \multicolumn{2}{|c|}{ IQI mm } & \multirow{2}{*}{$\begin{array}{l}\text { Gęstość } \\
\text { optyczna }\end{array}$} & & \\
\hline & & & & wymagana & uzyskana & & & \\
\hline 1 & a & BOR 1 & $\mathrm{~B}$ & 0,20 & 0,20 & 2,5 & 502 & $\mathrm{~B}$ \\
\hline 2 & a & BOR 2 & $\mathrm{~B}$ & 0,20 & 0,20 & 2,5 & 502 & B \\
\hline 3 & a & BOR 3 & B & 0,20 & 0,20 & 2,5 & 502 & B \\
\hline
\end{tabular}


Celem ujawnienia budowy mikrostrukturalnej na próbkach wykonano zgłady, które trawiono nitalem i poddawano obserwacji na mikroskopie optycznym. Na rysunku 7 przedstawiono przykłady struktury poszczególnych stref złącza.

Oznaczenie badania: PN-EN 1321-A-E-3.1-3.1-3.1 /Adler.
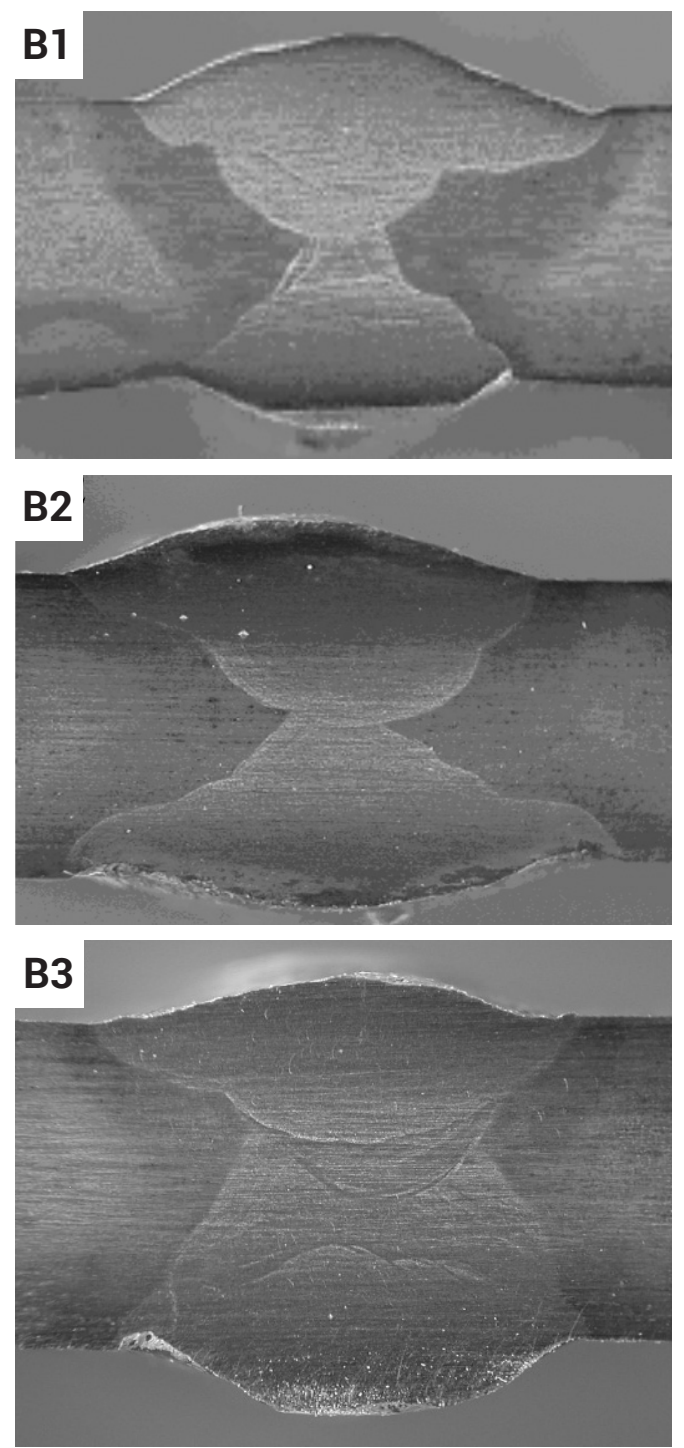

Rys. 6. Przekroje makro złączy próbnych. Widoczny układ ściegów. Niezgodności wewnętrznych nie stwierdzono

Fig. 6. Macro sections of test joints. Visible weld seems. Internal imperfestions no found.

Oznaczenie badania: PN-EN 1321-I-E-3-1-3 /Nital.

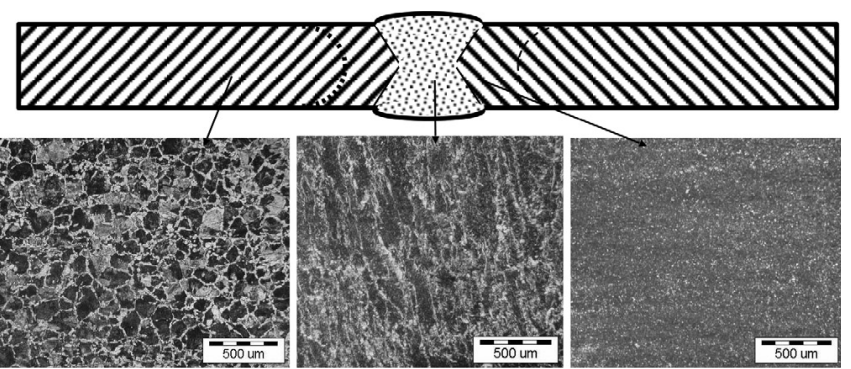

Rys. 7. Struktury mikroskopowe elementów złącza próbnego. Mikroskop optyczny OLYMPUS. Widoczna struktura ferrytyczno - perlityczna materiału rodzimego, dendrytyczna spoiny i drobno dyspersyjna strefy wpływu ciepła

Fig. 7. Macrostructure of the test joint. Optical microscope Olympus. The ferritic - pearlitic structure of the base material, dendritic weld and fine dispersion heat affected zone

\section{Próba rozciągania RM wg PN-EN 895}

Ocenę właściwości wytrzymałościowych złączy próbnych wykonano na próbkach paskowych po mechanicznym usunięciu nadlewów lica. Rozciąganie wykonywano na maszynie wytrzymałościowej ZDTe-30. Wyniki próby zestawiono w tablicy VIII. Obydwie próbki pękły w materiale rodzimym. Na rysunku 8 widok próbki po badaniu.

Tablica VIII. Wyniki próby rozciągania złącza próbnego Table VIII. >>>>>>>>>>>>>>>>>>>>>>>>>>>>>>>>>>>>>>>

\begin{tabular}{|c|c|c|c|c|c|}
\hline Lp & Próbka & $\begin{array}{c}\text { Przekrój } \\
\text { próbki }\end{array}$ & $\begin{array}{c}\mathrm{R}_{\mathrm{m}} \\
(\mathrm{MPa})\end{array}$ & $\begin{array}{c}\mathrm{R}_{0,2} \\
(\mathrm{MPa})\end{array}$ & $\begin{array}{c}\mathrm{A} \\
(\%)\end{array}$ \\
\hline 1 & $\mathrm{R} 1$ & $17.2 \times 8$ & 643 & 489 & 23 \\
\hline 2 & $\mathrm{R} 2$ & $18.5 \times 8$ & 647 & 491 & 25 \\
\hline
\end{tabular}

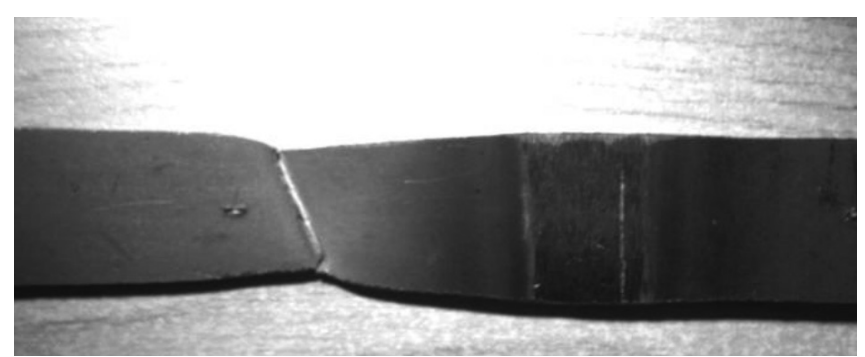

Rys. 8. Próbka paskowa złącza po zerwaniu. Widoczny przełom w materiale rodzimym

Fig. 8. Weld sample after tensile testing. Visible crack in the base metal

\section{Próba zginania poprzecznego MG wg PN-EN 910}

Ocenę plastyczności złącza przeprowadzono w przyrządzie gnącym rolkowym przedstawionym schematycznie na rysunku 9. Zastosowano trzpień gnący d $=32 \mathrm{~mm}$. Odległość między rolkami wynosiła I = $56 \mathrm{~mm}$ przy kącie gięcia $180^{\circ}$. Gięto po dwie próbki FBB i dwie RBB. Pęknięć powierzchniowych i naderwań nie zaobserwowano.

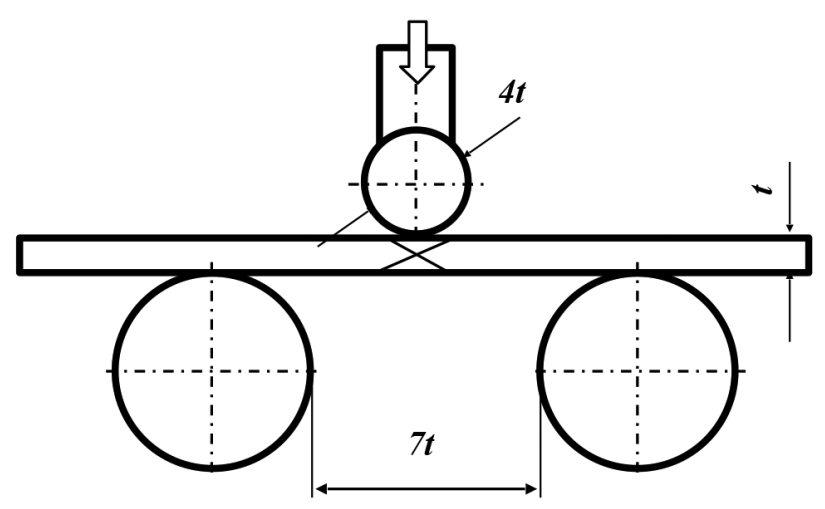

Rys. 9. Schemat przyrządu do gięcia próbek złączy spawanych. Fig. 9. Scheme of jig for welded joints bending

\section{Próba wdrożenia technologii spawania stali 28HGVB}

$\mathrm{Na}$ podstawie pozytywnych wyników oceny spawalności, przeprowadzono próby regeneracji lemieszy pługów rolniczych. Na rysunku 10 przedstawiono wygląd nowego i zregenerowanego lemiesza. Zużyty lemiesz uzupełniono elementami z ulepszanej cieplnie stali 28HGVB metodą spa- 
wania łukowego elektrodą otuloną EB 150 (wg EN ISO 2560A: E42 4 B 42). Próby polowe potwierdziły wysoką trwałość regenerowanego lemiesza.
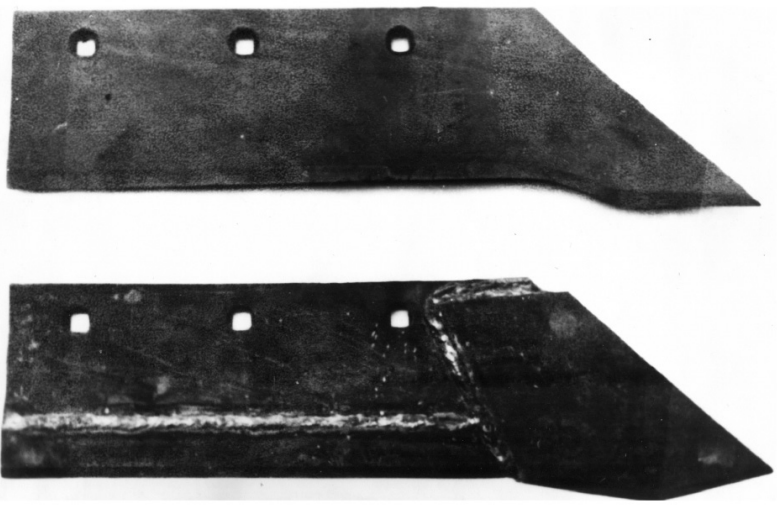

Rys. 10. Lemiesz nowy i po próbie regeneracji

Fig. 10. The new ploughshare and after regeneration

\section{Omówienie wyników badań}

Badana stal 28HGVB jest interesującym materiałem konstrukcyjnym i narzędziowym, zwłaszcza w aspekcie zastosowania na elementy pojazdów i maszyn wymagające wysokiej wytrzymałości i odporności na ścieranie. Na takie właściwości główny wpływ mają dodatki stopowe, a zwłaszcza bor. Stal 28HGVB wykazuje wysoką wytrzymałość na rozciąganie wynoszącą około $640 \mathrm{MPa}$, przy wydłużeniu ok. $20 \%$.

Rysunek 2 przedstawia rozkład twardości stali z mikrododatkiem boru (28HGVB) w funkcji odległości od czoła próbki, zwany krzywą hartowności. Twardość stali zahartowanej w próbie Jominy'ego wynosi na czole próbki 523 HV. Można zatem stwierdzić, że stal 28 HGVB jest stalą o dobrej hartowności, a co za tym idzie możliwości uzyskiwania znacznej twardości na głębokość wymaganą w elementach roboczych maszyn pracujących w trudnych warunkach.

Utwardzania stal mikrostopowa daje możliwość uzyskiwania wysokiej odporności na zużycie ścierne. Zaprogramowanie twardości stali na różnych poziomach możliwe jest przez odpuszczenie w temperaturze $220{ }^{\circ} \mathrm{C}, 350{ }^{\circ} \mathrm{C}$ Czy $500{ }^{\circ} \mathrm{C}$. Dla wymienionych temperatur odpuszczania uzyskano odpowiednio twardość $470 \mathrm{HV}, 420 \mathrm{HV}$ i $330 \mathrm{HV}$. Ocena odporności obrobionej cieplnie stali na uderzenia wykazała, że w badanym zakresie temperatur odpuszczania stal 28HGVB nie wykazała kruchości. Kąt zgięcia był proporcjonalny do temperatury odpuszczania.

$Z$ reguły hartowność jest cechą przeciwstawną spawalności. Przy niskiej zawartości węgla spawalność jest dobra, a hartowność niska na skutek braku odpowiedniej ilości węgla potrzebnego do przesycenia żelaza a. Przy wysokiej zawartości węgla, hartowność jest dobra, ale podczas krzepnięcia spoiny następuje utwardzanie i pękanie SWC.

Spawalność określona równoważnikiem węglowym $\mathrm{CE}=0,34$ mówi o możliwości powstawania kruchości w złączu. Na podstawie uzyskanej informacji opracowano instrukcję spawania powszechnie stosowaną metodą 111 z wstępnym podgrzewaniem złącza do $150^{\circ} \mathrm{C}$.

Badania laboratoryjne mające na celu określenie przydatności stali z borem do spawania przeprowadzono wg normy na uznanie technologii spawania PN-EN ISO 15614-1. Wykonano trzy próby spawania materiału o grubości $8 \mathrm{~mm}$ elektrodą otuloną EB 150. Wyniki badań wizualnych, radiograficznych, makroskopowe i mechanicznych wypadły pomyślnie. Złącza zakwalifikowano do poziomu jakości B. Podczas badań makroskopowych złącza spawanego za- obserwowano trzy charakterystyczne strefy. Pierwsza z nich to materiał rodzimy, druga strefa wpływu ciepła i trzecia spoina. Każdą z tych stref można jednoznacznie wyodrębnić. Badania makroskopowe pozwalają zaobserwować zmiany w materiale, które zaszły podczas procesu spawania. Wywołane one zostały wpływem ciepła, a także pozwalają stwierdzić czy materiał poddany procesowi spawania nie uległ uszkodzeniu w obszarze złącza. Przeprowadzenie badań mikroskopowych pozwoliło zaobserwować różną dyspersję ziaren struktury stali 28 HGVB w trzech charakterystycznych miejscach: w materiale rodzimym, strefie wpływu ciepła oraz spoinie. Struktura jaką zaobserwowano w całości materiału podstawowego to struktura perlitycznoferrytyczna po normalizacji. Bezpośredni wpływ na dyspersję struktury ma temperatura stygnięcia materiału. Ziarna w materiale rodzimym są największe i najbardziej regularne gdyż na materiał w tej części nie miała wpływu istotna zmiana temperatury podczas procesu spawania. Ziarna struktury materiału rodzimego ukształtowały się w procesie walcowania gdzie nie występowały nagłe spadki temperatury. W strefie wpływu ciepła zmiana temperatury podczas procesu spawania miała największy wpływ na strukturę. Zaobserwowano tutaj strukturę drobno dyspersyjną. Trzecia charakterystyczna strefa w której zaobserwowano odmienną strukturę to spoina. W wyniku spadku temperatury podczas krystalizacji powstała struktura dendrytyczna tzn. ziarna o orientacji zgodnej z kierunkiem odpływu ciepła.

W ocenie rozkładu mikrotwardości stwierdzono utwardzenie złącza w strefach wpływu ciepła, co wskazuje na możliwość wystąpienia kruchości. Próba pozwoliła określić twardość stali 28HGVB w trzech charakterystycznych miejscach, to jest: w materiale rodzimym, strefie wpływu ciepła oraz w spoinie. Zaobserwowano podobną wartość twardości w materiale rodzimym oraz spoinie (około 240 HV), natomiast twardość materiału w strefie wpływu ciepła jest znacznie większa i sięga poziomu $340 \mathrm{HV}$. Oznacza to, że stal 28 HGVB uległa podhartowaniu w strefie wpływu ciepła co potwierdziły badania mikroskopowe. Różnica twardości stali $28 \mathrm{HGVB}$ pomiędzy trzema charakterystycznymi miejscami może wpływać niekorzystnie na wytrzymałość złącza spawanego, gdyż spowoduje jego podatność na pękanie przy obciążeniu [11].

Przeprowadzona próba zginania pozwoliły stwierdzić, że plastyczność złącza pozostała na wymaganym poziomie. $\mathrm{Na}$ próbkach nie zaobserwowano żadnych pęknięć na granicy materiału rodzimego i spoiny, a także w samej spoinie.

Jedną z procedur oceny spawalności była próba rozciągania złącza. Na podstawie przeprowadzonych badań wyznaczono wytrzymałość złącza próbnego na rozciąganie, a przede wszystkim określono wpływ procesu spawania na strukturę łączonego materiału. Po przeprowadzonej próbie rozciągania zaobserwowano, że próbki uległy zerwaniu w materiale rodzimym co świadczy o poprawnej wytrzymałości złącza bez względu na poziom naprężeń. Granica maksymalnej wytrzymałości $R m=643 \mathrm{MPa}$ i $\mathrm{Rm}=647 \mathrm{MPa}$ jest na oczekiwanym poziomie dla stali 28HGVB w stanie znormalizowanym. Na granicy strefy wpływu ciepła i spoiny, a także w samej spoinie nie stwierdzono żadnych uszkodzeń (np.: przewężenie próbki, pęknięcia). Granicę plastyczności wynoszącą $R 0,2 \approx 490 \mathrm{MPa}$, należy traktować jako umowną gdyż złącze jest niejednorodne pod względem twardości i odkształcało się nierównomiernie. Stal 28HGVB można określić mianem stali uniwersalnej, gdyż jest to materiał, która charakteryzuje się możliwością utwardzenia, a zarazem dobrą spawalnością i wysoką wytrzymałością przede wszystkim złącz spawanych. Stal ta powinna mieć duże zastosowanie w produkcji przede wszystkim maszyn rolniczych, budowlanych, górniczych [8] i innych pracujących w warunkach wysokich obciążeń i synergicznego 
zużycia ścierno - korozyjno - wodorowego. Ze względu na dobrą spawalność może być stosowana na ulepszane cieplnie elementy robocze spawane do korpusów. Cecha ta umożliwia również prowadzenie napraw i regeneracji narzędzi metodami spawalniczymi co zostało potwierdzone w próbie praktycznej. Spawanie metodą 111 umożliwiło uzyskiwanie złączy próbnych o poziomie jakości B.

Odporność na ścieranie i obciążenia dynamiczne występujące w środowisku pracy danego narzędzia można regulować temperaturą odpuszczania.

\section{Wnioski}

Na podstawie wyników przeprowadzonych badań można stwierdzić, że stal 28HGVB z mikrododatkiem boru:

1. Posiada zarówno dobrą hartowność jak i spawalność.

2. Wykazuje podatność na utwardzanie po hartowaniu i odpuszczaniu do 330-470 HV.

3. Wykazuje wysoką odporność na obciążenia udarowe po obróbce cieplnej.

4. Jest pod względem technologicznym uniwersalnym tworzywem konstrukcyjnym.

5. Może być stosowana na nowoczesne spawane konstrukcje uprawowe, transportowe i budowlane jak również do odtwarzania zużytych elementów roboczych.

\section{Literatura}

[1] Brózda J., Pilarczyk J., Zeman M., Spawalnicze wykresy przemian austenitu CTPc-S. Wyd. Śląsk. Katowice 1983 s. 7-9, 24-25.

[2] Choi H.S. and other. Evaluation of weldability for resistance spot welded single-lap joint between GA780DP and hot-stamped 22MnB5 steel sheets Journal of Mechanical Science and Technology 25 (6) (2011) $1543-1550$.

[3] Dutka K., Stabryła J. Jakość złączy w procesie wytwarzania i napraw konstrukcji spawanych. Konferencja Wydziału Mechanicznego „Doskonalenie techniki i technologii w przemyśle i rolnictwie". Olsztyn 1996.

[5] Konat Ł., Pękalski G., Structures and selected properties of Hardox steels in the context of their use in surface mining machinery construction. XV International Symposium on Mine Planning \& Equipment Selection (MPES 2006), 20 - 22 September 2006, Torino - Italy, vol. 1 , str. $142 \div 147$.

[6] Kupczyk J., Lis A.K. Wpływ boru na kinetykę przemian fazowych stali 1021. 12- th International Scentificit Conference AMME 2003 s.547-550.

[7] Lee H. W., Kim Y. H., Lee S. H., Lee S. K., Lee K. H., Park J. U. and Sung J. H., Effect of boron contents on weldability in high strength steel, Journal of Mechanical Science and Technology, 21 (2007) p.771-777.'

[8] Pękalski G., Wybrane zagadnienia materiałowe elementów maszyn górnictwa odkrywkowego narażonych na zużywanie ściernie, a możliwości zastosowania stali Hardox. Górnictwo Odkrywkowe, nr 4/5, str. 47-53, 2005.
[9] PN-EN ISO 15614-1:2008 Specyfikacja i kwalifikowanie technologii spawania metali. Badanie technologii spawania. Część 1: Spawanie łukowe i gazowe stali oraz spawanie łukowe niklu i stopów niklu.

[10] Satora R. Ryś J., Bor jako pierwiastek stopowy w stalach. Referat III Konferencji Naukowo-Technicznej Huty Stalowa Wola, 1980, s. 5-27.

[11] Stabryła J. Dutka K.: Analiza awarii konstrukcji spawanych. Przegląd Spawalnictwa. 6/2008, s. 15-21.

[12] Stabryła J, Starczewski L, Łunarska E, Wpływ agresywnego środowiska gleby na zużycie narzędzi rolniczych. Trybologia. Zeszyt 32005 r.

[13] Stabryła J. Quality of steel for agriculture machine elements . Chapter 3. "Quality materials improvment 2007 " pod redakcją S. Borkowski, H.Dyja. Edis University of Zilina, 2007. p. 20-26.

[14] Tasak E.: Spawalność stali. Wydawnictwo FOTOBIT, Kraków 2002.

[15] Węglowski M. St.: Nowoczesne stale ulepszane cieplnie - własności, korzyści z zastosowania. Biuletyn Instytutu Spawalnictwa, 2012. nr 3.

[16] Willms R.: High strength steel for steel constructions. Nordic Steel Construction Conference - NSCC, 2009, 597-604.

[17] Wolak Z., Stabryła J., Technologia stosowana w produkcji lemieszy, a właściwości tworzywa i trwałość narzędzia. Rocznik Nauk Rolniczych 1988, t. 77-C-4, s. 191-205. 